\title{
PENERAPAN METODE SWOT PADA SISTEM INFORMASI PENJADWALAN MATA PELAJARAN (Studi Kasus:SMA TRISAKTI BATURAJA)
}

\author{
Sri Tita Faulina \\ Program Studi Manajemen Informatika, AMIK AKMI Baturaja \\ Email: sritita@akmi-baturaja.ac.id
}

\begin{abstract}
Abstrak
Dalam Perkembangan teknologi saat ini kehadiran komputer sebagai pengolah data dalam masa sekarang ini banyak membawa perubahan, baik dalam dunia pendidikan, usaha, instansi-instansi pemerintah, maupun swasta. SMA Trisakti Baturaja belum menggunakan aplikasi khusus dalam pengolahan data jadwal pelajaran. Penelitian ini dilakukan untuk mempelajari, menganalisis dan merancang masalah yang berkaitan dengan pemilihan strategi yang tepat untuk membangun sistem informasi pengolah jadwal pelajaran. Yang akan diterapkan di SMA Trisakti Baturaja. Pemilihan strategi ini menggunakan analisis SWOT. Analisis SWOT adalah identifikasi berbagai faktor secara sistematis untuk merumuskan strategi yang ada pada SMA Trisakti Baturaja. Berdasarkan hasil matriks Internal- Eksternal pada analisis SWOT, Dengan perancangan sistem informasi Penjadwalan Mata Pelajaran ini diharapkan agar dapat mempermudah dalam mengelola data guru, data kelas, data pengampu, data waktu, data pelajaran, dan mencetak semua laporan, sehingga SMA Trisakti Baturaja menghasilkan sistem kinerja lebih cepat, tepat dan akurat. Adapun hasil penelitian ini dapat digunakan Harapannya dengan adanya sistem informasi ini dapat membantu bagian tata usaha SMA Trisakti Baturaja dalam pengolah jadwal pelajaran.
\end{abstract}

Kata kunci: Informasi, Pengolahan Data, Sistem Informasi SWOT, Sistem

\begin{abstract}
In the current technological developments the presence of computers as data processors in the present has brought many changes, both in the world of education, business, government agencies, and the private sector. SMA Trisakti Baturaja has not yet used a special application in processing lesson schedule data. This research was conducted to study, analyze and design problems related to the selection of the right strategy to build an information system processing schedule lesson. Which will be applied at SMA Trisakti Baturaja. The selection of this strategy uses a SWOT analysis. SWOT analysis is a systematic identification of various factors to formulate existing strategies at SMA Trisakti Baturaja. Based on the results of the InternalExternal matrix in the SWOT analysis, the design of this information system is expected to facilitate teacher data management, class data, supporting data, time data, lesson data, and print all reports, so that SMA Trisakti Baturaja produces a system faster, more precise and accurate performance. The results of this study can be used. Hopefully the existence of this information system can help the administration of SMA Trisakti Baturaja in processing the schedule of lessons.
\end{abstract}

Keywords - Information, Data Processing, SWOT Information Systems, Systems 


\section{PENDAHULUAN}

Perkembangan teknologi informasi yang semakin pesat dan ini merupakan tantangan berat bagi pengguna teknologi informasi itu sendiri dan mendorong setiap sektor organisasi baik formal maupun informal atau lembaga-lembaga lainnya dalam hal pemanfaatan tekhnologi yang membantu kegiatan penunjang kerja yang menghasilkan informasi yang cepat, tepat dan akurat. Maka dibutuhkan sumber daya pendukung lainnya seperti perangkat lunak yang dapat diandalkan kemampuannya serta sumber daya manusia yang harus menguasai kemampuan teknologi informasi itu sendiri dan menyusun strategi-strategi.

Banyaknya produkprodukpengolahan data yang diinginkan untuk informasi yang dibutuhkan dalam dunia perkantoran ataupun pendidikan. Sistem informasi memiliki peranan penting dalam kegiatan perusahaan atau pendidikan. SMA Trisakti Baturaja adalah salah satu lembaga pendidikan menengah atas. Jadwal mata pelajaran di sekolah merupakan hal yang sangat penting dalam berlangsungnya kegiatan belajar mengajar di SMA Trisakti Baturaja. Secara umum jadwal mata pelajaran berfungsi untuk mendukung, memperlancar aktivitas akademik dalam menjaga kualitas mengajar dan kedisiplinan baik guru maupun siswa.

Kegiatan yang rutin dilakukan oleh bidang kurikulum yaitu menyusun jadwal mata pelajaran. Menyusun jadwal mata pelajaran dilakukan dengan teliti agar tidak terjadinya kerangkapan data. Penyusunan jadwal mata pelajaran saat ini masih dilakukan dengan pembukuan menggunakan form atau buku penjadwalan pelajaran kemudian dipindahkan ke dalam microsoft excel. Selama ini masih sering terjadinya kerangkapan data guru, data mata pelajaran, dan pengubahan jadwal secara berulang-ulang. Dalam proses penyusunan jadwal mata pelajaran yang dilakukan secara pembukuan tersebut membutuhkan banyak waktu sehingga informasi yang dihasilkan belum tentu akurat.

Penulis berinisiatif akan merancang sebuah sistem menggunakan aplikasi khusus sehingga dapat menjawab permasalahan selama ini. Dari permasalahan tersebut peneliti akan membuat sistem informasi penjadwalan mata pelajaran dan. Dengan adanya sistem informasi ini diharapkan permasalahan dalam penginputan data guru, data kelas, data mata pelajaran, data pengampu dan data jadwal pelajaran dapat dilakukan secara cepat dan akurat yang menghasilkan laporan penjadwalan mata pelajaran. Sehingga dapat meringankan bidang kurikulum dalam pembuatan jadwal pelajaran dan Penetapan strategi menggunakan analisis SWOT. Analisis SWOT adalah identifikasi berbagai faktor secara sistematis untuk merumuskan strategi yang ada pada SMA Trisakti Baturaja. Berdasarkan hasil matriks Internal- Eksternal pada analisis SWOT, Dengan perancangan sistem informasi Penjadwalan Mata Pelajaran ini diharapkan agar dapat mempermudah dalam mengelola data guru, data kelas, data pengampu, data waktu, data pelajaran, dan mencetak semua laporan. Dengan adanya aplikasi sistem jadwal mata pelajaran, kegiatan belajar mengajar akan berjalan dengan lancar dan efisien. Sehingga kegiatan belajar mengajar di sekolah bisa dilaksanakan secara maksimal.

\section{TINJAUAN PUSTAKA}

\subsection{Pengertian Sistem}

Terdapat dua kelompok pendekatan didalam mendefinisikan sistem, yaitu yang menekankan pada prosedurnya dan yang menekankan pada komponen atau elemennya. Pendekatan sistem yang menekankan pada prosedur mendefinisikan sistem merupakan suatu jaringan kerja dari 
prosedur-prosedur yang saling berhubungan, berkumpul bersama-sama untuk melakukan suatu kegiatan atau untuk menyelesaikan suatu sasaran yang tertentu[1]. Sedangkan Pendekatan sistem merupakan jaringan kerja dari prosedur lebih menekankan urutan-urutan operasi didalam sistem.

Pendekatan sistem yang lebih menekankan pada elemen atau komponennya mendefinisikan sistem adalah Kumpulan dari elemen-elemen yang berinteraksi untuk mencapai suatu tujuan tertentu yang mana komponen-komponen atau subsistem-subsistem saling berinteraksi dan saling berhubungan membentuk satu kesatuan sehingga tujuan atau sasaran sistem tersebut dapat tercapai. Untuk menganalisis sistem dan merencanakan suatu sistem, analisis dan perancangan sistem harus mengetahui terlebih dahulu mengenai komponenkomponen dari sistem tersebut.

Berdasarkan hal diatas, definisi secara umum mengartikan sistem sebagai kumpulan elemen-elemen yang saling berinteraksi dan bertanggung jawab memproses masukan (input) sehingga menghasilkan keluaran (output).

\subsection{Pengertian Sistem Informasi}

Dalam mempelajari sistem kita harus mempelajari informasi, pasalnya suatu sistem yang kurang mendapatkan suatu informasi akan menjadi ketinggalan zaman/tidak bertahan lama. Informasi dapat berupa data mentah, data tersusun dan sebagainya, dimana data adalah suatu kenyataan yang bermanfaat menggambarkan suatu kejadian-kejadian dan kesatuan yang nyata. Gagasan penting yang mendasari pemakaian istilah informasi dalam sistem informasi adalah memperkaya penyajian, mempunyai nilai kejutan atau mengungkapkan sesuatu. Informasi dapat merubah kemungkinan-kemungkinan hasil yang diharapkan dalam sebuah situasi keputusan.

Karena itu Informasi mempunyai nilai dalam proses keputusan. Iinformasi adalah :Data yang diolah menjadi bentuk yang lebih berguna dan berarti bagi penerimanya [1]. Informasi secara umum dalam pemakaian sistem informasi adalah Data yang telah diolah menjadi sebuah bentuk yang berarti dan berguna bagi penerimanya untuk mengambil keputusan masa kini maupun yang akan datang[2].

Sedangkan Informasi adalah data yang telah diolah menjadi bentuk yang lebih berarti bagi penerimanya[2]. Jadi dapat disimpulkan bahwa Informasi adalah data yang dirubah/diproses menjadi bentuk yang lebih berguna dan berarti dalam pengambilan keputusan.

Sistem yaitu sekelompok yang menekankan pada prosedur dan kelompok yang menekankan pada elemen atau komponenya pendekatan yang menekankan pada prosedur mendefinisikan sistem sebagai suatu jaringan kerja dari prosedur prosedur yang saling berhubungan, berkumpul bersama-sama untuk melakukan suatu kegiatan atau menyelesaikan suatu sasaran tertentu[3].

Model umum sebuah sistem terdiri dari input, proses dan output, hal ini merupakan konsep sebuah sistem yang sangat sederhana mengingat sebuah sistem dapat mempunyai beberapa pemasukkan dan pengeluaran sekaligus[3]. Selain itu sebuah sistem juga memiliki karakteristik atau sifat-sifat tertentu, yang mencirikan bahwa hal tersebut bisa dikatakan sebagai suatu sistem.

Adapun karakteristik yang dimaksud adalah sebagai berikut:

1. Komponen sistem (components)

Suatu sistem yang terdiri dari sejumlah komponen yang saling berinteraksi, yang berkerjasama membentuk satu kesatuan. 
2. Batasan sistem sistem (Boundary)

Ruang lingkup sistem merupakan daerah yang membatasi antara sistem dengan sistem lainya atau sstem dengan lingkungan luarnya.

3. Lingkungan Luar sistem (Environtment) Bentuk apapun yang ada di luar lingkup atau batasan sistem yang mempergaruhi operasi sistem tersebut disebut dengan lingkungan luar dari sistem

4. Penghubung sistem (Interface) Sebagai media yang menghubungkan sistem dengan sub sistem yang lainnya.

5. Masukkan sistem (input)

Energi yang dimasukkan kedalam sistem disebut masukkan sistem, yang berupa pemeliharaan (maintenance input) dan sinyal (signal input).

6. Keluaran sistem (output)

Hasil dari energy yang diolah dan di klarifikasikan menjadi keluaran yang berguna.

7. Pengolahan sistem (proses)

Suatu sistem dapat mempunyai suatu proses yang akan mengubah masukkan menjadi pengeluaran.

8. Sasaran sistem (objective)

Suatu sistem memiliki tujuan dan sasaran yang pasti dan sifat deterministik.

Sistem Informasi adalah data yang telah diolah untuk digunakan untuk mengambil keputusan[3]. Sistem pengolahan informasi akan mengelolah data menjadi informasi atau pengolah data dari bentuk tak berguna menjadi berguna bagi penerimanya. nilai informasi berhubungan dengan keputusan. bila tidak ada pilihan atau keputusan maka informasi tidak diperlukan keputusan dapat berkisar dari keputusan maka informasi tidak diperlukan.

Teori informasi lebih tepat disebut sebagai teori matematika komunikasi yang memberikan pandangan yang berguna bagi sistem informasi, yang mana konsep informasi menunjukkan hubungan interval informasi, sumber dari informasi adalah data.

\subsection{Kualitas Informasi}

Informasi yang memiliki kualitas baik akan menentukan efektifitas dalam pengambilan keputusan pada suatu organisasi. John Burch dan Gary Grudnitski menyebutkan adanya tiga pilar utama yang menentukan kualitas dari suatu informasi yaitu : Akurat, Tepat pada waktunya dan Relevan. Informasi yang menjelaskan dengan rinci dan lengkap tentang syarat-syarat Informasi yang dikatakan berkualitas yaitu apabila mempunyai karakteristikkarakteristik[3]sebagai berikut:
1. Akurat
2. Relevan
3. Tepat Waktu
4. Ekonomis
5. Efisien
6. Dapat Dipercaya

\subsection{Analisis SWOT}

Analisis SWOT adalah Suatu metode perencanaan strategis untuk mengevaluasi factor-faktor yang berpengaruh dalam usaha mencapai tujuan, yaitu kekuatan (strengths), kelemahan (weaknesses), peluang (opportunities), dan ancaman (threats), baik itu tujuan jangka pendek maupun jangka panjang.

\subsection{Analisis Keunggulan SWOT}

Bertujuan untuk membuat evaluasi kekuatan, kelemahan, peluang dan ancaman dalam bisnis. Umumnya SWOT digambarkan dengan tabel pada ukuran kertas besar untuk memudahkan analisis hubungan antar aspeknya, dengan melibatkan tujuan bisnis yang spesifik dan identifikasi faktor internal dan eksternal unutk mencapai tujuan tersebut. Adapun keunggulan suatu Penjadwalan dengan menggunakan analisis SWOT adalah sebagai berikut : 
a. Bagian kurikulum menjadi lebih memahami kekuatannya dan memberikan rekomendasi untuk meningkatkannya.

b. Bagian kurikulum dapat melihat situasi suatu peluang dan dapat mempertahankan peluang.

c. Bagian kurikulum mengetahui kelemahan serta mencari solusi untuk mengurangi kelemahan tersebut.

d. Bagian kurikulum mengetahui potensi ancaman serta untuk menghindari ancaman tersebut

\subsection{Analisis Kebutuhan Sistem dan SWOT}

Bertujuan untuk mempermudah analisis sistem dalam mementukan keseluruhan kebutuhan secara lengkap. Maka kebutuhan tersebut terbagi bagi menjadi dua jenis, yaitu:

1) Kebutuhan Fungsional

2) Kebutuhan Nonfungsional

Sedangkan Analisis SWOT berperan dalam bisnis karena tujuannya membuat kerangka situasi dan kondisi dalam suatu perusahaan dari sudut pandang SWOT (Strength, Weaknesses, Opportunities, threats)

\subsection{Komponen Sistem Informasi}

Sistem informasi berbasis komputer (CBIS) dalam suatu organisasi terdiri dari komponen-komponen[4] berikut :

1. Perangkat Keras (Hardware)

Mencakup berbagai peranti fisik seperti komputer dan printer.

2. Perangkat Lunak (Software)

Program atau instruksi yang memungkinkan perangkat keras memproses data.

3. Basis Data (Database)

Kumpulan data dan informasi yang diorganisasikan sedemikian rupa sehingga cepat dan mudah diakses oleh pengguna sistem informasi.

4. Prosedur (Procedure)

Sekumpulan aturan yang meliputi strategi, kebijakan, metode dan peraturan-peraturan dalam menggunakan sistem informasi berbasis komputer.

5. Telekomunikasi

Komunikasi yang menghubungkan antara pengguna sistem dengan sistem komputer secara bersama-sama kedalam suatu jaringan kerja yang efektif.

6. Orang (Manusia)

Semua pihak yang bertanggung jawab dalam pengembangan sistem informasi, pemrosesan dan penggunaan keluaran sistem informasi.

\section{METODOLOGI PENELITIAN}

3.1 Metodologi Pengembagan System

Dalam melakukan pengembangan sistem sangat diperlukan suatu metodologi dalam mendefinisikan pendekatanpendekatan pengembangan. Tercapainya sasaran dari pengembangan sistem dipengaruhi oleh pendekatan dan metodologi yang digunakan dalam perencanaan dan perancangan sistem.

Metodologi merupakan pedoman bagaimana dan apa yang harus dikerjakan dalam mengembangkan sistem. Metodologi yang digunakan dalam pengembangan sistem Data Penjadwalan Mata Pelajaran adalah metodologi waterfall.

Waterfall adalah suatu teknik pengembangan sistem untuk merencanakan, memutuskan dan mengontrol proses pengembangan sistem informasi. Tahapantahapan dalam melakukan pengembangan sistem yang menggunakan model waterfall adalah sebagai berikut :
a. Perencanaan (Planing)
b. Analisis (Analysist)
c. Perancangan (Design)
d. Penerapan (Implementation)
e. Pemeliharaan (Maintenance) 


\subsection{Analisis Sistem}

Analisis sistem dapat diartikan sebagai Penguraian dari sistem informasi yang utuh kedalam bagian komponen dengan maksud untuk mengidentifikasi dan mengevaluasi permasalahan, kesempatan, hambatan yang terjadi dan kebutuhan yang diharapkan sehingga dapat diusulkan perbaikan-perbaikan.

Tahap analisis data sistem dilakukan setelah tahap perencanaan sistem dan sebelum tahap desain sistem.

Tahap analisa merupakan tahap yang sangat penting karena kesalahan dalam tahap ini menyebabkan kesalahan pada tahap selanjutnya. Selanjutnya langkahlangkah dasar yang harus ditempuh dalam tahap analisis adalah :

1. Identify, yaitu mengidentifikasi masalah.

2. Understand, yaitu memahami kerja dari sistem yang ada.

3. Analyze, yaitu menganalisa sistem.

4. Report, yaitu membuat laporan.

\subsection{Identifikasi Masalah Dan Penyebab Masalah \\ Mengidentifikasi \\ Masalah}

merupakan langkah pertama yang dilakukan dalam analisis sistem. Masalah dapat didefinisikan sebagai suatu hal yang ingin dipecahkan.Masalah inilah yang menyebabkan sasaran sistem tidak dapat dicapai.Oleh karena itu tahap pertama yang harus dilakukan pada tahap analisis sistem adalah mengidentifikasi trelebih dahulu masalah masalah yang terjadi.

Untuk mengidentifikasi masalah tersebut dapat dilakukan dengan mengkaji terlebih dahulu subyek-subyek yang telah diuraikan oleh manajemen atau yang telah ditemukan oleh analis sistem di tahap perencanaan sistem. Untuk kasus ini masalah- masalah yang terjadi adalah sebagai berikut :
1. Pengendalian terhadap data jadwal pelajaran yang kurang terkontrol dengan baik karena mengelola data guru, data kelas, data pengampu, data waktu, data pelajaran, yang kadang ada jadwal pelajaran yang sering double dan tidak terinputkan.

2. Data mata pelajaran dalam bentuk arsip dari tahun ketahun banyak yang hilang sehingga mencari data jadwal pengampu yang dibutuhkanpun mengalami kesulitan.

3. Pencatatan data mengelola data guru, data kelas, data pengampu, data waktu, data pelajaran dilakukan melalui Microsoft Excel sehingga menyita waktu ketika akan dilakukan pengecekan data kembali maupun pencarian data.

4. Proses pembuatan laporan penjadwalan membutuhkan waktu yang lama.

Dari permasalahan permasalahan tersebut diatas dapat diidentifikasi bahwa penyebab utama masalah yang terjadi adalah karena pengolahan datanya masih dilakukan secara manual yaitu dengan mengandalkan kertas untuk pengarsipan data. Selain itu juga belum tersedianya program aplikasi yang dapat membantu untuk mengolah dan menganalisis laporan.

\subsection{Analisis Kelayakan Sistem}

Dalam pengerjaan Sistem baru yang ditawarkan harus diuji kelayakannya terlebih dahulu, apakah sistem tersebut lebih baik dari yang sudah ada atau malah sebaliknya. Dalam mengerjakan pengujian kelayakan-kelayakan ini harga atau biaya yang harus dikeluarkan dan manfaat yang dapat diperoleh akan dipertimbangkan secara matang baik oleh SMA Trisakti Baturaja secara umum maupun oleh bagian kepegawaian yang membutuhkan informasi yang disediakan oleh sistem. Untuk menguji apakah suatu sistem dapat 
dikatakan layak atau tidak maka dapat dilakukan beberapa analisis diantaranya adalah analisis kelayakan teknik, analisis kelayakan sosial, analisis kelayakan hukum, analisis kelayakan operasi dan analisis kelayakan ekonomi.

\subsection{Perancangan Model}

Model dari sistem informasi yang diusulkan akan disajikan dalam dua bentuk, yang pertama yaitu phisical model, bentuk ini digambarkan dengan bagan alir sistem (Program flowchart) yang akan menunjukkan kepada user bagaimana nantinya sistem yang diusulkan bekerja secara fisik. Dan bentuk kedua adalah logical model, model ini akan menggambarkan dengan diagram arus data (data flow diagram) yang akan menjelaskan kepada user bagaimana nantinya fungsi-fungsi di sistem informasi yang diusulkan secara logika akan bekerja.

\subsection{Perancangan Basis Data}

Perancangan basis data dimaksudkan untuk mendefinisikan isi atau struktur dari tiap-tiap file yang telah diidentifikasikan pada desain secara umum. Teknik normalisasi akan digunakan dalam perancangan database secara rinci ini agar diperoleh basis data yang efisien dalam penggunaan ruang penyimpanan, cepat dalam pengaksesan dan mudah dalam pemanipulasian data.

\section{HASIL DAN PEMBAHASAN}

\subsection{Hasil}

Hasil antarmuka (interface) sistem yang terdiri dari berbagai menu dan sub menu dalam pengoperasian sistem yang terdiri dari 6 menu yaitu input, pengolah, cari, laporan, bantuan dan keluar.

1. Form Login

Fungsi login ini adalah agar admin dapat masuk dan mengakses programnya setelah dilakukan validasi yang biasanya berupa user name dan password. Sedangkan fungsi password adalah untuk mengecek kecocokan data dengan user name yang diinputkan ketika akan melakukan login.

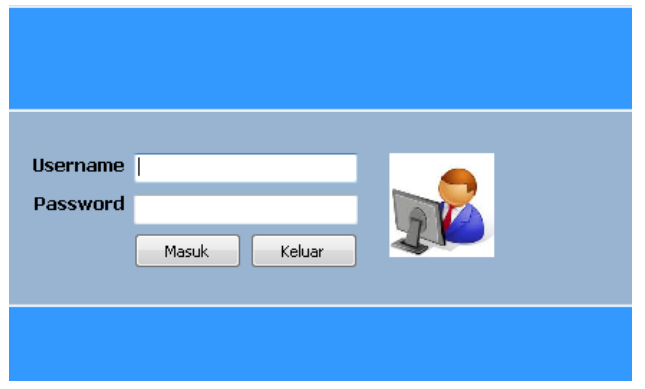

Gambar 1. Tampilan form login

\section{2. Мепи Utama}

Menu utama digunakan untuk memilih form yang ingin dibuka. Menu utama akan muncul setelah admin memasukkan user name dan password terlebih dahulu. Adapun tampilan menu utama Sistem Informasi Penjadwalan Mata Pelajaran SMA Trisakti Baturaja.

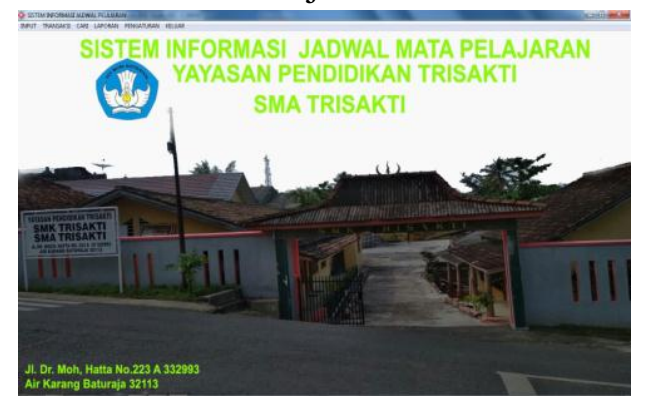

Gambar 2. Tampilan menu utama

\section{Menu Input}

Menu input terdiri dari input data guru, input data mata pelajaran, input data kelas, dan input data waktu .

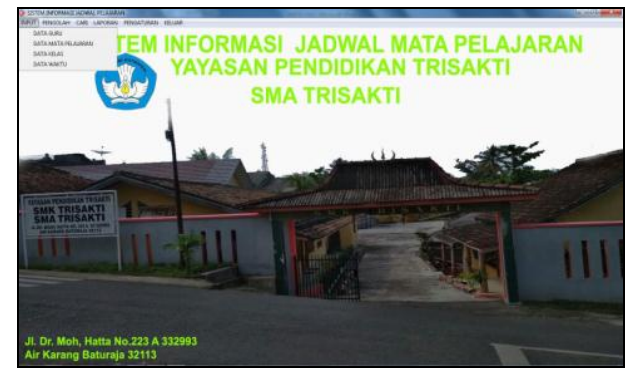

Gambar 3. Tampilan menu input 


\section{Input Data Guru}

Form Data Guru adalah form yang digunakan untuk mengelola data guru yang ada di SMA Trisakti Baturaja.

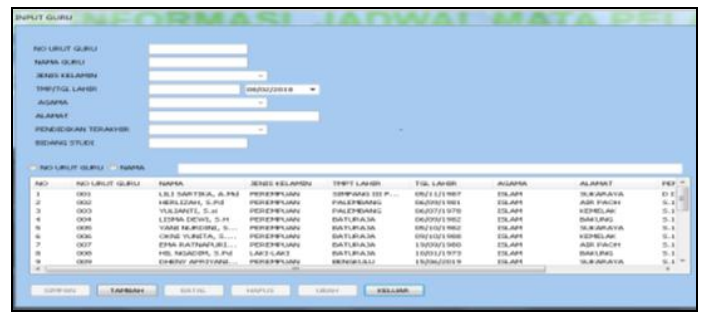

Gambar 4. Tampilan input data guru

5. Input data mata pelajaran

Form Data mata pelajaran adalah form yang digunakan untuk mengelola data mata pelajaran yang ada di SMA Trisakti Baturaja.

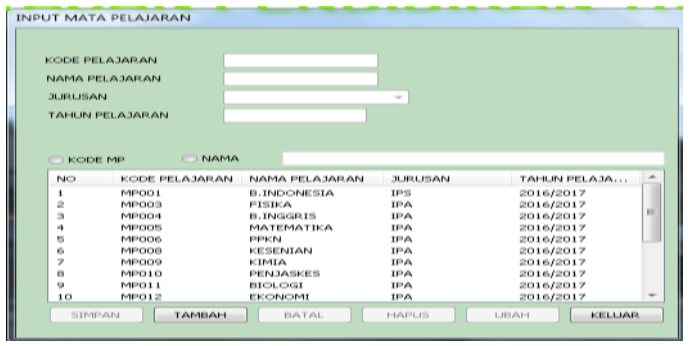

Gambar 5. Tampilan input mata pelajaran

\section{Input data kelas}

Form Data kelas adalah form yang digunakan untuk mengelola data kelas yang ada di SMA Trisakti Baturaja.

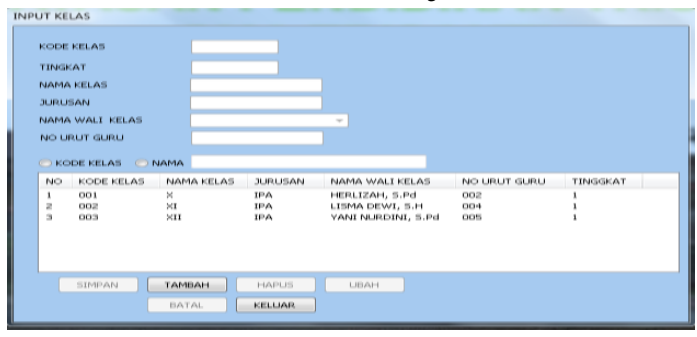

Gambar 6. Tampilan input data kelas

\section{Input data waktu}

Form Data waktu adalah form yang digunakan untuk mengelola data waktu yang ada di SMA Trisakti Baturaja.

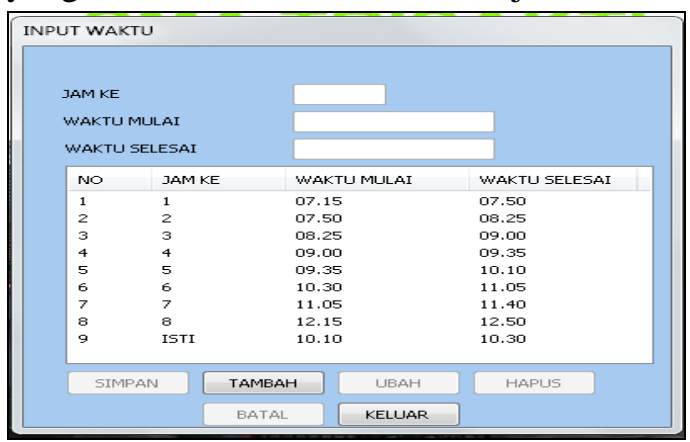

Gambar 7. Tampilan input data waktu

8. Menu pengolah

Menu pengolah terdiri dari data pengampu dan jadwal mata pelajaran.

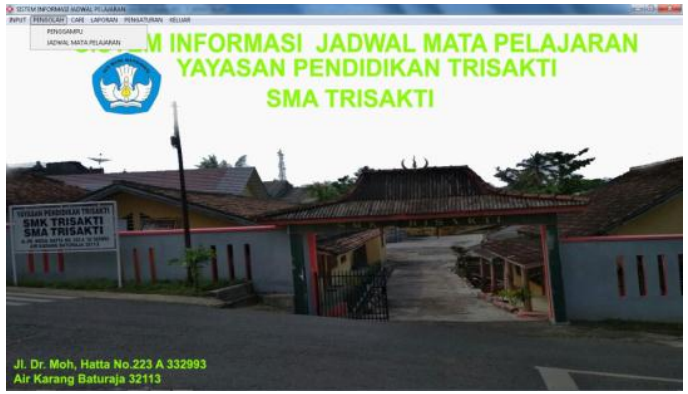

Gambar 8. Tampilan menu pengolah

\section{Input data pengampu}

Form Data Pengampu adalah form yang digunakan untuk mengelola data pengampu yang ada di SMA Trisakti Baturaja.

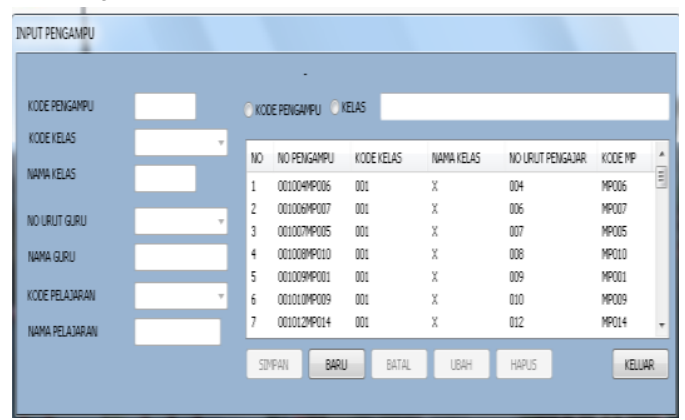

Gambar 9. Tampilan input data pengampu 
10. Input jadwal mata pelajaran

Form Data jadwal mata pelajaran adalah form yang digunakan untuk mengelola data jadwal mata pelajaran yang ada di SMA Trisakti Baturaja.

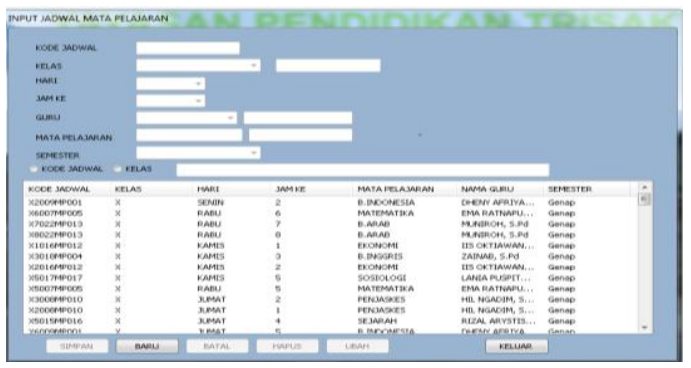

Gambar 10. Tampilan input jadwal pelajaran

\section{Menu Pencarian Data}

Menu Pencarian terdiri dari data guru, data mata pelajaran, data kelas dan pengampu, data jadwal mata pelajaran.

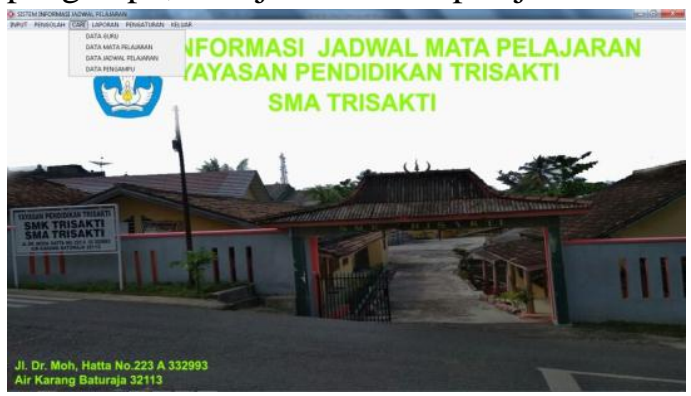

Gambar 11. Tampilan menu pencarian data

12. Pencarian data guru

Form data guru adalah form yang digunakan untuk melakukan pencarian data guru, cara pencarian pilih no urut guru atau nama guru.

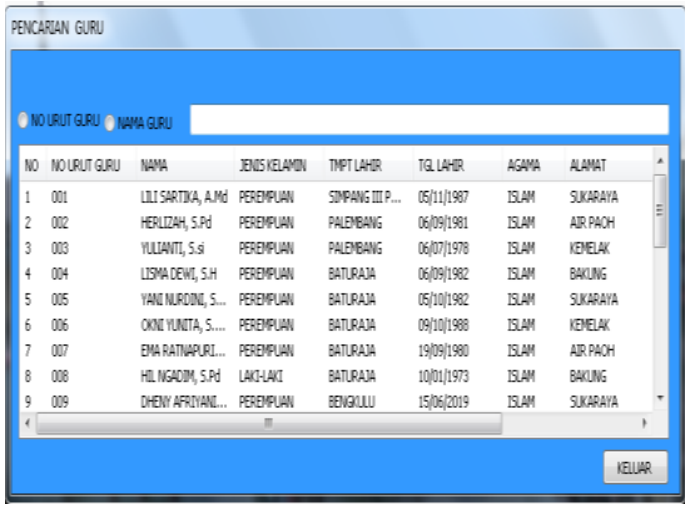

Gambar 12. Tampilan pencarian data guru
13. Pencarian data mata pelajaran

Form data mata pelajaran adalah form yang digunakan untuk melakukan pencarian data mata pelajaran, cara pencarian pilih kode mata pelajaran atau nama mata pelajaran.

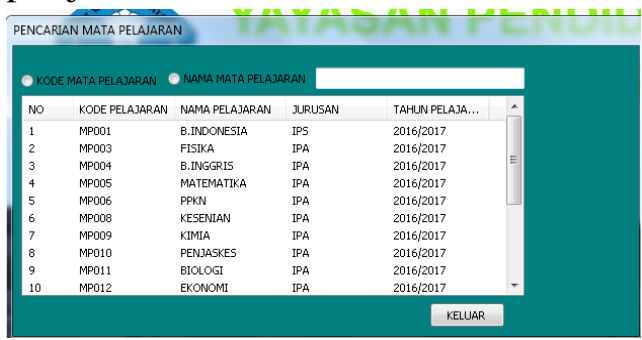

Gambar 13. Tampilan pencarian data mata pelajaran

14. Pencarian data pengampu

Form data pengampu adalah form ang digunakan untuk melakukan pencarian data pengampu, cara pencarian pilih kode pengampu atau nama kelas.

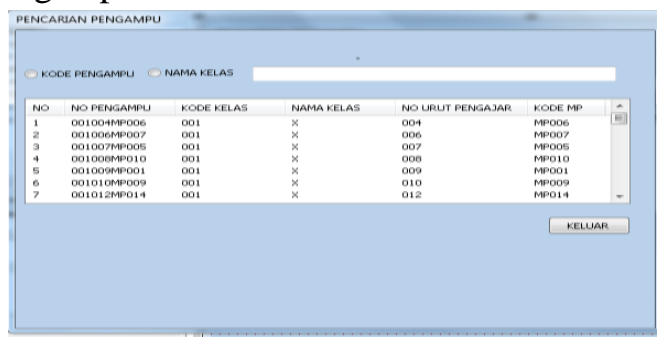

Gambar 14. Tampilan pencarian data kelas dan pengampu

15. Pencarian data kelas dan jadwal pelajaran

Form data kelas dan jadwal pelajaran adalah form yang digunakan untuk melakukan pencarian data kelas dan jadwal pelajaran, cara pencarian pilih kode kelas atau nama wali kelas.

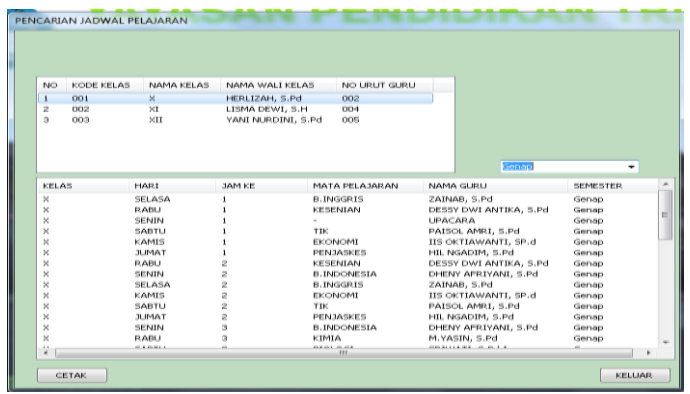

Gambar 15. Tampilan pencarian jadwal pelajaran 


\section{Menu laporan}

Menu laporan terdiri dari laporan data guru, laporan data mata pelajaran, laporan data kelas, laporan data pengampu, laporan data jadwal pelajaran.

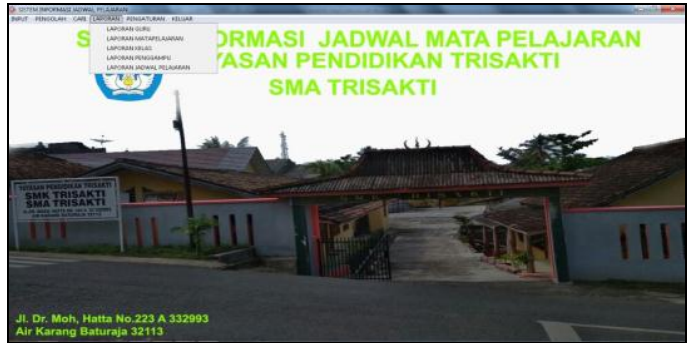

Gambar 16. Tampilan menu laporan

17. Laporan data guru

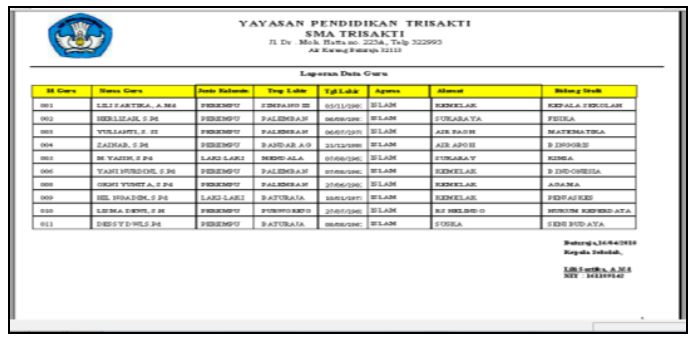

Gambar 17. Tampilan laporan guru

18. Laporan data kelas

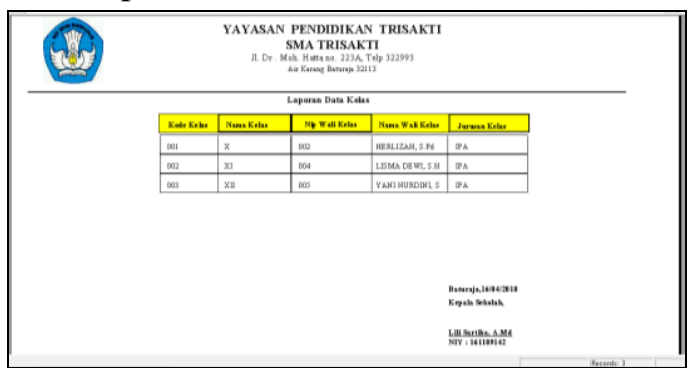

Gambar 18. Tampilan laporan kelas

19. Laporan data mata pelajaran

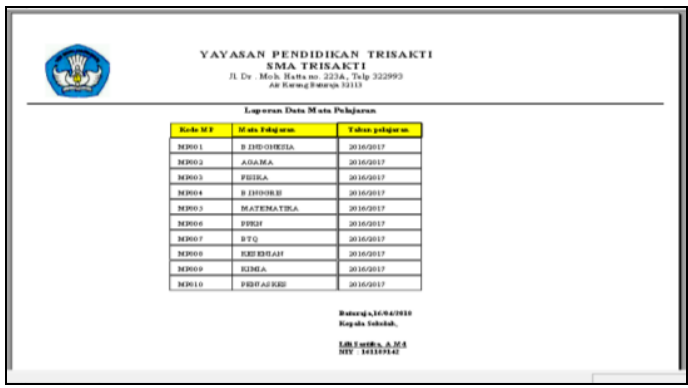

Gambar 19.TTampilan laporan mata pelajaran
20. Laporan data jadwal pelajaran

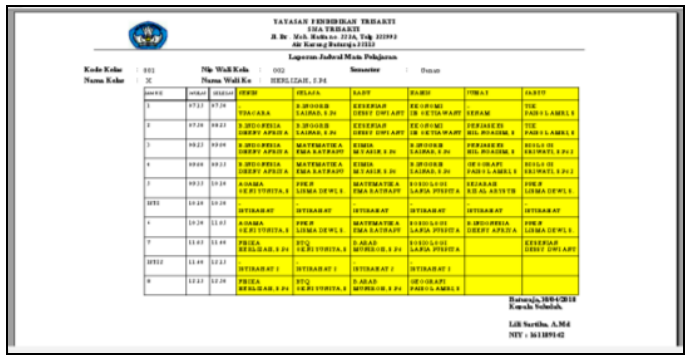

Gambar 20. Tampilan laporan jadwal Pelajaran

21. Laporan data pengampu

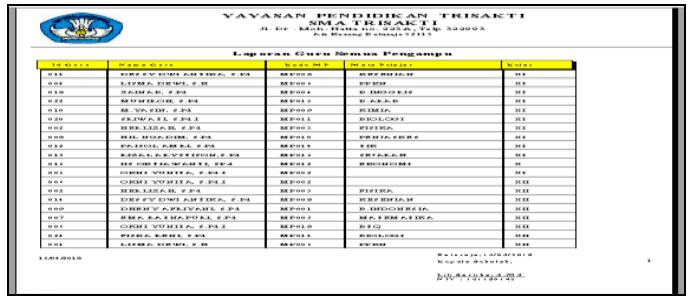

Gambar 21. Tampilan laporan pengampu

\section{Menu pengaturan}

Menu pengaturan hanya menyediakan form ubah sandi.

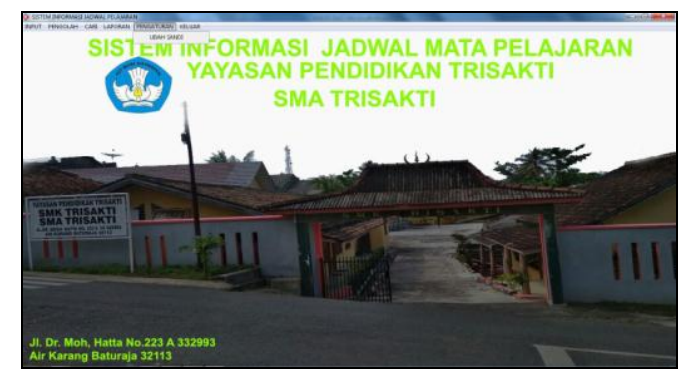

Gambar 22. Tampilan menu pengaturan

\subsection{Implementasi Sistem}

Implementasi sistem (system implementation) adalah tahap untuk meletakkan suatu sistem supaya siap untuk dioperasikan. Aplikasi Sistem Informasi Pejadwalan Mata Pelajaran ini diimplementasikan dengan menggunakan program Embarcadero Delphi Xe2 sebagai interface, sedangkan untuk penyimpanan database menggunakan Microsoft Access 2007.

Tahap implementasi sistem meliputi rencana implementasi yang merupakan 
awal ditahap implementasi yang bertujuan untuk mengatur biaya dan waktu yang dibutuhkan selama tahap implementasi sistem. Selanjutnya pada tahapan ini adalah melakukan kegiatan yang mendukung dalam pembuatan sistem yang telah dirancang sebelumnya. Adapun rencana kegiatan yang dilakukan dalam tahap implementasi sistem adalah sebagai berikut

a) Pengujian Program

b) Pengujian Sistem

c) Manual Program

d) Manual Instalasi

e) Pemilihan Dan Pelatihan Personil

f) Konversi Sistem

g) Pemeliharaan Sistem

h) Tindak Lanjut Implementasi

\section{KESIMPULAN}

Setelah menyelesaikan Implementasi Metode SWOT pada analisis dan perancangan Sistem Informasi Penjadwalan Mata Pelajaran SMA Trisakti Baturaja, maka dapat disimpulkan sebagai berikut:

a. Dalam menggunakan Microsoft access sebagai Database Management System (DBMS) yang didukung oleh Embarcadero Delphi XE2 sistem usulan ini dapat melakukan utilisasi dan memaintenance data dalam jumlah yang besar.

b. Sistem usulan ini mampu menghasilkan laporan data guru, data kelas, data pengampu, data waktu, data pelajaran dan laporan.

c. Proses pengecekan data maupun pencarian data bisa dilakukan dengan cepat dan mudah.

\section{SARAN}

Adapun beberapa saran yang ingin penulis sampaikan adalah sebagai berikut:

1. Hal penting yang perlu diperhatikan dengan adanya sistem yang baru adalah melakukan perawatan terhadap hardware dan software dengan baik.

2. Dengan adanya sistem usulan ini, SMA Trisakti Baturaja disarankan untuk memperhatikan kekurangan dan kelemahan sistem agar dapat segera dicari pemecahan masalahnya dan dapat segera diperbaiki.

3. Sistem yang dirancang ini hanya dapat digunakan untuk pengolahan data guru, data kelas, data pengampu, data waktu, data pelajaran, dan laporan sehingga sistem ini diharapkan nantinya dapat dikembangkan lagi sehingga menghasilkan informasi yang lengkap.

\section{DAFTAR PUSTAKA}

[1] Jogiyanto, Sistem Teknologi Informasi. Yogyakarta: CV ANDI OFFSET, 2009.

[2] A.-B. Bin Ladjamudin, Analisis dan Desain Sistem Informasi. Yogyakarta: Graha Ilmu, 2005.

[3] T. Sutabri, Analisis Sistem Informasi. Yogyakarta: Andi, 2012.

[4] R. . Stair, Quantitave Analysis For Management. New York, 1992. 